International Journal of Linguistics, Literature and Translation (IJLLT)

ISSN: 2617-0299 (Online); ISSN: 2708-0099 (Print)

DOI: $10.32996 / \mathrm{jjllt}$

Journal Homepage: www.al-kindipublisher.com/index.php/ijllt

\title{
Exploring Teachers' Readiness to Teach Purposive Communication
}

Ma. Theresa L. Eustaquio ${ }^{1 *}$ \& Juanito P. Tandoc Jr. ${ }^{2}$

${ }^{12}$ Isabela State University Echague Campus, Philippines

Corresponding Author: Ma. Theresa L. Eustaquio E-mail: thessa18e@gmail.com

ARTICLE INFO

Received: November 10, 2020

Accepted: December 21, 2020

Volume: 3

Issue: 12

DOI: 10.32996/ijllt.2020.3.12.17

\section{KEYWORDS}

New General Education

Curriculum, Curriculum Reform,

Philippine General Education

Curriculum, higher education

\section{ABSTRACT}

This paper addresses the issues concerning teachers' preparedness to teach purposive communication and how do they prepare in teaching the course. In order to come up with the needed data, the researcher made use of the explanatorysequential design. A questionnaire was administered to the respondents and recorded interviews were conducted. Data revealed that in terms of teaching competencies, teaching strategies and instructional materials, the teachers were "very well ready" in teaching Purposive Communication. The responses of the teachers during the interview confirmed the initial results stating that teacher training and retooling, curriculum reform and realignment, teacher preparation and use of varied classroom pedagogies made them prepared to handle this new course. On the contrary, their responses also revealed that there were issues, problems and concerns governing the implementation of this course like the availability of technological devices and sequencing of subject matter.

\section{Introduction}

In the last 30 years or so, many countries in the world over partake in curriculum reforms which have been intended to adjust and align the contents and pedagogies of the general education curriculum to suit and address the changing social, economic and cultural context and to meet the demands brought about by global development (Ranaweera, 2000). In response to these reforms, the aims and objectives of general education over the years have been stretched, broadened and its scope expanded. Thus, the long before approaches and strategies to curriculum enhancement, instructional pedagogies, evaluation materials and teacher education and preparation that were designed and appropriate in the academe that were relatively stable are of course no longer valid. Hence, the educational system should be re-oriented and should be aligned towards future progressions, giving due consideration to concerns such as knowledge versus learning and problem-solving skills, a national versus a global outlook, and the maintenance of values and cultural identity amidst the impact of socioeconomic and technological changes.

Over the past decades, the Philippine Educational System promises quality curriculum. Significant reforms were concluded to target the needs not only of the nation but most importantly the learners. It endeavors to ensure that the educational curriculum is in tandem with country's developmental needs, university's vision and mission statement, and of course present-day needs of the learners of the curriculum. In 1996, the Commission on Higher Education created a General Education Curriculum. In 1997, the commission renamed this as GEC-A and created an alternative curriculum called GEC-B.

Thus, prompted and driven by curricular changes and reform to address and align the requirements and needs of 21 st century learners to the trends and necessities of today's academic standards, the Commission of Higher Education implemented the New General Education Curriculum during the school year 2018-2019 (CMO No. 20, s. of 2013). The new curriculum strongly mandates the holistic development of every learner. Hence, this new curriculum offers core set of skills-Critical Thinking and Problem Solving, Collaboration Across Networks and Leading by Influence, Agility and Adaptability, Initiative and

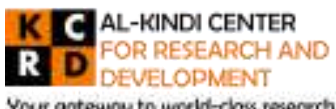

Your gatewoy to world-class reeorch
Published by Al-KindiCenter for Research and Development. Copyright (c) the author(s). This is an open access article under CC BY license (https://creativecommons.org/licenses/by/4.0/) 
Entrepreneurialism, Effective Oral and Written Communication, Accessing and Analyzing Information, and Curiosity and Imagination (Wagner, 2008, p. 14-38)- skills which are needed to be possessed by the learners.

Downgrading some of the General Education courses in the senior high school curriculum created a window for the revision of the current General Education curriculum. While R.A. 10533 (Enhanced Basic Education Act of 2013) increased its number of years, from the then 10 years to now 12 years, the new GEC took advantage on considering the College Readiness Standards and focusing and avoiding duplication of courses, strongly aligning the courses to the needs of the present generation. The then 64 units to the now 32 units of new GEC promised no duplication of courses. Likewise, with great consideration to the contention of educational experts that the there is a mismatch between the labor market and the educational system (e.g. Jovović, Đurašković \& Radović, 2017; Allen \& Weert, D.E., 2007; Cedefop, 2010; Croce \& Ghignoni, 2015; Modestino, A.S., 2010), curriculum experts designed the new GEC as a tool in honing and enhancing the skills of the learners matching the skills needed in the labor market.

Purposive Communication (PC), the only language and communication course in the new general education curriculum, offers myriad of skills' enhancement to the learners. Based on the syllabus provided by CHED, PC is a three-unit course that develops students' competency to express themselves in English, develops and enhances their multicultural and intercultural awareness while being closely and deeply rooted to their own cultures by doing and accomplishing multi-modal tasks and projects that provide them opportunities to use the English language effectively and appropriately in a given local or global context. Students also will be exposed to various domains of knowledge by thinking globally while acting locally- making glocalization possible in all the areas of the course. Moreover, the course equips students with tools for critical evaluation of a variety of texts and focuses on the power of language and the impact of images to emphasize the importance of conveying messages responsibly.

Furthermore, bounded by Outcomes-Based Education which is a learner-centered educational model that focuses on the learning outcomes of students (Driscoll \& Wood, 2007), Purposive Communication course targets specific outcomes for each topic indicated in its syllabus. Likewise, while the old general English courses typically ascribe equal attention to the four language skills (listening, reading, speaking, and writing), the then English for Specific Purposes (ESP) now Purposive Communication focuses only on those skills that are known to be relevant to the learner's target profession (Teodorescu, 2010) making the course learner specific and outcome-based course.

Applying the tenets of ESP, in addition to the specific competencies needed in the business workplace and in the academic world, Purposive Communication have also highlighted and stressed out the significance of cultural awareness and knowledge as it is inextricably linked to language (Drobot, 2014). It is therefore, crucial that students are trained to be "flexibly competent" to adapt and respond appropriately to the cultural nuances of local and international business professionals. Supportive of this contention, St. John (1996, as cited in Lockwood, 2012) suggests that, "an interdisciplinary approach (to ESP for business) is called for to take account of language, interpersonal communication skills, business know-how, and cultural issues" (p. 16). Evidently, cultural knowledge and multilingual practices in the workplace is deeply inculcated in this new general education course.

With the requirements of the course, Purposive Communication, it is evident therefore that the graduates of K12 should possess various skills before taking new GE. Since the new GEC was implemented just recently, there were no available resources to prove that graduates of the K12 curriculum is now ready to face the challenges of the new curriculum.

However, even though this curriculum reform geared towards the promise of competency, proficiency and mastery of the skills mentioned, the outcome is dependent on how the teachers enact change and how the learners absorb these changes. Thus, the attainment of the goals of this new GEC lies solely on its implementers.

Since its implementation, there have been concerns and issues that beg immediate attention and remediation. Though trainings were conducted and instructional materials were at hand, there were no available literature concerning the preparedness and readiness of the teachers and students to teach and learn in the new curriculum. Issues on the complexity of subject matter and requirements were aired by faculty members handling the course; authenticity and applicability of the instructional materials used; and the use of technological devices as well as internet connectivity were also the concerns of most teachers in different universities. With these issues at hand, the need to come up with a study in the preparedness of teachers in the new curriculum is deemed necessary. 


\section{Literature Review}

Purposive Communication (PC), the only language and communication course in the new general education curriculum, offers myriad of skills' enhancement to the learners. Based on the syllabus provided by CHED, PC is a three-unit course that develops students' competency to express themselves in English, develops and enhances their multicultural and intercultural awareness while being closely and deeply rooted to their own cultures by doing and accomplishing multi-modal tasks and projects that provide them opportunities to use the English language effectively and appropriately in a given local or global context. Students also will be exposed to various domains of knowledge by thinking globally while acting locally- making glocalization possible in all the areas of the course. Moreover, the course equips students with tools for critical evaluation of a variety of texts and focuses on the power of language and the impact of images to emphasize the importance of conveying messages responsibly.

Furthermore, bounded by Outcomes-Based Education which is a learner-centered educational model that focuses on the learning outcomes of students (Driscoll \& Wood, 2007), Purposive Communication course targets specific outcomes for each topic indicated in its syllabus. Likewise, while the old general English courses typically ascribe equal attention to the four language skills (listening, reading, speaking, and writing), the then English for Specific Purposes (ESP) now Purposive Communication focuses only on those skills that are known to be relevant to the learner's target profession (Teodorescu, 2010) making the course learner specific and outcome-based course.

Applying the tenets of ESP, in addition to the specific competencies needed in the business workplace and in the academic world, Purposive Communication have also highlighted and stressed out the significance of cultural awareness and knowledge as it is inextricably linked to language (Drobot, 2014). It is therefore, crucial that students are trained to be "flexibly competent" to adapt and respond appropriately to the cultural nuances of local and international business professionals. Supportive of this contention, St. John (1996, as cited in Lockwood, 2012) suggests that, "an interdisciplinary approach (to ESP for business) is called for to take account of language, interpersonal communication skills, business know-how, and cultural issues" (p. 16). Evidently, cultural knowledge and multilingual practices in the workplace is deeply inculcated in this new general education course.

While a great number of researches focus on the teacher and curriculum and its relation to students' performance (Lynch, Smith, Provost, Yeigh \& Turner, 2017; Leithwood, Harris, and Hopkins, 2008; Shen and Cooley, 2008; Lachat and Smith, 2005; Marzano et al., 2005; Hattie, 2009, 2011, 2012; Hargreaves and Fullan, 2012), this research paper focuses on the extent of readiness of teachers in teaching Purposive Communication. Therefore, it shall explore the extent of preparedness of Isabela State University Echague Campus teachers in teaching Purposive Communication. Exploring the insights of teachers in this new English curriculum will not only add to the limited number of researches conducted along this line but the results of this study will aid in the enhancement of content and pedagogy used in teaching Purposive Communication, development of Instructional Materials, and prioritization and proper allocation of training among faculty and staff of the program. Thus, this paper will answer the following research questions:

1. To what extent is the readiness of the instructors/professors in the implementation of the new GEC in terms of:
a. teaching competencies;
b. teaching strategies; and
c. instructional materials?

2. How do the teachers prepare in teaching Purposive Communication?

\section{Methodology}

\subsection{Participants}

The respondents for the quantitative part of the study were the 21 faculty members from the College of Arts and Sciences and College of Education Isabela State University Echague Campus, Philippines teaching Purposive Communication. 8 faculty members were also chosen as participants of this study.

Thus, total population was considered in the gathering of the quantitative data and purposive sampling was employed in the gathering of the qualitative data. 


\subsection{Design}

The study employed mixed-method specifically the Explanatory Sequential Design which implies collecting and analyzing first the quantitative and then qualitative data in two consecutive phases within one study (Tashakkori and Teddlie 1998; Creswell 2003, 2005; Creswell et al. 2003). The study therefore consists of two distinct phases: quantitative followed by qualitative (Creswell et al. 2003).

In this design, the researcher first collected and analyzed the quantitative (numeric) data. The qualitative (text) data were collected and analyzed second in the sequence and help explain, or elaborate on the quantitative results obtained in the first phase. The rationale for this approach is that the quantitative data and their subsequent analysis provide a general understanding of the research problem. This design can be especially useful when unexpected results arise from a quantitative study (Morse 1991).

\subsection{Data Gathering Procedure}

To ensure that the ethical considerations were followed, letters of request were addressed to the head of the campus and to the individual respondents before conducting the actual gathering of the needed data. With their permission and willingness, administering of survey questionnaires and interviews were scheduled based on their availability.

For the interview part, to "ensure the most direct, research-focused interaction between research and participant" (Kazmer \& Xie, 2008, p.258; Kvale, 1996) and to elicit more natural responses for the problem, all the respondents were interviewed in locations of their own choice, on the assumption that they would be more comfortable in a familiar environment (Tandoc, 2016). The respondents were guaranteed of anonymity and were told that they could refuse to answer any question or stop the interview at any time, and that participation is exclusively voluntary (Fraenkel \& Wallen, 2006). Before conducting the interviews, the purpose and design of the study were presented to assure that everyone will receive consistent orientation. The interviews will be tape-recorded and transcribed accurately and cleansed from "transfer error" through corrective listening (Flick et al., 2004).

The transcribed result of the interviews was subjected to phenomenological reduction through the construction of a repertory grid or coding. The grid served as a tool for the researcher to observe both cool and warm analyses (Lartek \& Espique, 2012). The cool analysis part consisted of the identification of the significant statements highlighted in the recorded interview. These statements served as basis in the conduct of the warm analysis stage where the data categories were formulated and where themes evolved (Tandoc, 2016). Member checking via correspondence technique was also conducted after the themes were derived from the transcribed results and codes (Lincoln \& Guba, 1985; Patton, 1990). The technique was conducted by the researcher to assure not only the trustworthiness but also the truthfulness of the data reported.

The following diagram shows how the data were collected and analyzed.

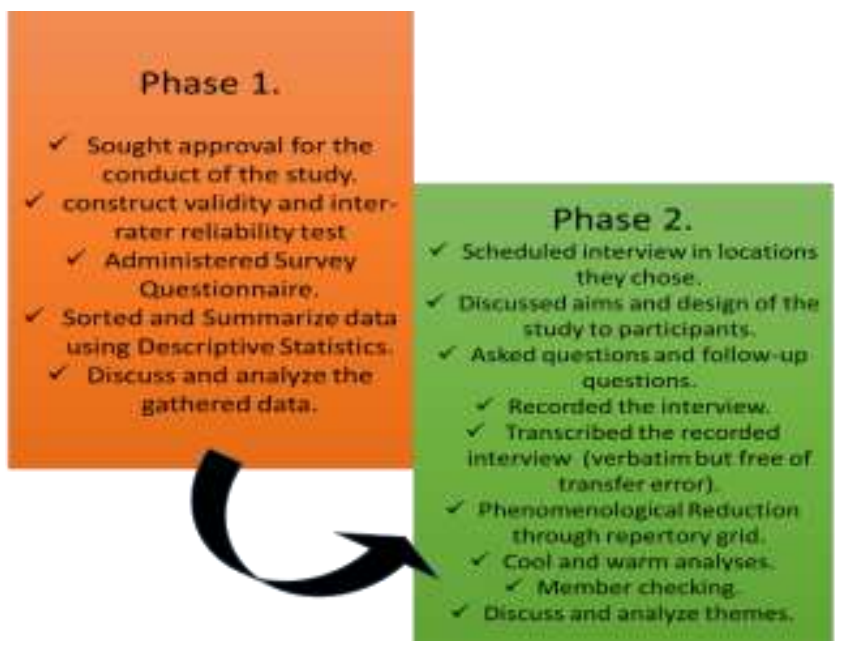

\subsection{Data Gathering Tools}

The instrument used in the study is a researcher-made questionnaire. It was used as the data gathering instrument with focus on teachers' readiness in terms of teaching competencies, teaching strategies and instructional materials. 
The instrument was subjected to Construct Validity by three experts in the field to ensure that the measure actually measures what it is intended to measure and not other variables. Then, a trial run of the instrument was conducted to 10 teachers of the university not covered by the study. They were not included as actual respondents but were used only for validation purposes to determine whether the contents of the questionnaire are comprehensible and reliable. Moreover, the results of the trial survey were analyzed and interpreted through the use of Split-Half method in association with Pearson Product-Moment Correlation and Spearman Brown Formula. As for the reliability of the instrument, the instrument was subjected to Inter-rater reliability test.

Likewise, the following scale was used in interpreting the computed weighted mean.

$\begin{array}{lll}\text { Weight } & \text { Scale/Range } & \text { Description } \\ 5 & 4.21-5.0 & \text { Very Well Ready } \\ 4 & 3.41-4.20 & \text { Moderately Well Ready } \\ 3 & 2.61-3.40 & \text { Ready } \\ 2 & 1.81-2.60 & \text { Moderately not ready } \\ 1 & 1.00-1.80 & \text { Not ready at all }\end{array}$

The quantitative data collected were analyzed using the SPSS Program. Descriptive statistics was conducted to determine the mean of the gathered data. For the qualitative part of the study, the main tool used during the interview is a recorder to capture the responses of the participants during the interview. Interview guides with their key questions was used. The interview questions were developed using A Priori Code.

\section{Results and Discussion Quantitative Phase}

Table 1. Teachers' Readiness to teach Purposive Communication in terms of Teaching Competencies

\begin{tabular}{lcc}
\hline Teaching Competencies & Mean & Qualitative Interpretation \\
\hline $\begin{array}{l}\text { 1. Varied types of teaching strategies are being used to suit } \\
\text { the needs of the new curriculum. }\end{array}$ & 4.00 & Moderately well ready \\
2. Employs more innovative techniques such as portfolio to & 4.33 & Very well ready \\
make learning more output base. & & Very well ready \\
3. Keeps abreast of the modern techniques of teaching, & 4.33 & Very well ready \\
particularly the use of multi-media. & 4.67 & Very well ready \\
$\begin{array}{l}\text { 4. Makes use of every possible resource to improve } \\
\text { themselves professionally, most particularly in terms of } \\
\text { instruction. }\end{array}$ & 4.67 & Moderately well ready \\
5. Utilizes more reliable assessment tools and techniques to \\
evaluate students' performance.
\end{tabular}

The readiness of teachers in terms of teaching competencies is shown in the above table. Most of the statements, 4 among 6 yielded "very well ready" and the remaining 2 yielded a qualitative interpretation of "moderately well ready". The statements "Makes use of every possible resource to improve themselves professionally, most particularly in terms of instruction." and "Utilizes more reliable assessment tools and techniques to evaluate students' performance." showed the highest mean, 4.67, and a QI of "very well ready". Statements "Employs more innovative techniques such as portfolio to make learning more output base." and "Keeps abreast of the modern techniques of teaching, particularly the use of multi-media." revealed 4.33 mean which resulted also to "very well ready". The statements with the lowest mean of 4.00, "Enhances teaching through using research-informed strategies." and "Varied types of teaching strategies are being used to suit the needs of the new curriculum." resulted to "Moderately well ready".

The foregoing findings conforms to the statement of Tigelaar et al. (2004). He mentioned that an integrated set of personal characteristics, knowledge, skills and attitudes are needed for effective performance in various teaching contexts. Furthermore, Zulaikha Mohamed, Martin Valcke \& Bram De Wever (2016) perceived mastery of core teacher competences is the indicator 
of the variable 'readiness-for-the-job'. Indeed, it is essential that teachers have precise knowledge of what they have to do and how to do it, for personal and short-term gains, such as enhancing job-performance and increasing self-confidence, as well as at the national level and for long-term gains, such as mitigating the rate of teacher-attrition (Rots, Kelchtermans \& Aelterman, 2012).

Table 2. Teachers' Readiness to teach Purposive Communication in terms of Teaching Strategies

\begin{tabular}{lcc}
\hline Teaching Strategies & Mean & Qualitative Interpretation \\
\hline $\begin{array}{l}\text { 1. Employs effective motivational techniques to sustain } \\
\text { students' interest in the lessons. }\end{array}$ & 4.33 & Very well ready \\
$\begin{array}{l}\text { 2. Presents lessons logically and sequentially and supports } \\
\text { them with concrete examples. }\end{array}$ & 4.67 & Very well ready \\
$\begin{array}{l}\text { 3. Phrases simple questions that encourage students' } \\
\text { participation. }\end{array}$ & 4.67 & Very well ready \\
$\begin{array}{l}\text { 4. Gives detailed and redundant explanations for difficult } \\
\text { points. }\end{array}$ & 4.33 & Very well ready \\
$\begin{array}{l}\text { 5. Directs discussion effectively and allow students to } \\
\text { participate in the discussion. }\end{array}$ & 4.67 & Very well ready \\
$\begin{array}{l}\text { 6. Gives clear and specific directions and emphasize the } \\
\text { values to be internalized during learning activities. }\end{array}$ & 4.67 & Very well ready \\
\hline
\end{tabular}

Table 2 revealed high mean values ranging from 4.67 to 4.33 which resulted to "very well ready" qualitative interpretation. Statements which got 4.67 means were "Presents lessons logically and sequentially and supports them with concrete examples."; "Phrases simple questions that encourage students' participation."; "Directs discussion effectively and allow students to participate in the discussion." and "Gives clear and specific directions and emphasize the values to be internalized during learning activities." The items "Employs effective motivational techniques to sustain students' interest in the lessons." and "Gives detailed and redundant explanations for difficult points." resulted to 4.33 mean.

Research findings dates back on 1995 clearly points out that the use of instructional approaches and strategies will hone learners' problem-solving ability and capacity to understand lessons (Dyer and Osborne, 1995). Likewise, Shin (1997) stressed that since the classroom is very dynamic and students came from different backgrounds and have different experiences, skills and abilities, teachers of such learners should use varied teaching strategies for these learners to easily grasp the idea being handed down by the teachers.

Table 3. Teachers' Readiness to teach Purposive Communication in terms of Instructional Materials

\begin{tabular}{lcc}
\hline Instructional Materials & Mean & Qualitative Interpretation \\
\hline $\begin{array}{l}\text { 1. Instructional materials are based on teachers' suitability } \\
\text { to attain the objectives of the lesson. }\end{array}$ & 4.00 & Moderately well ready \\
$\begin{array}{l}\text { 2. Instructional materials motivate and sustain the varied } \\
\text { interests of the students. }\end{array}$ & 4.33 & Very well ready \\
$\begin{array}{l}\text { 3. Instructional materials are consistent with students' } \\
\quad \text { capabilities and learning styles. }\end{array}$ & 4.67 & Very well ready \\
$\begin{array}{l}\text { 4. Mock-ups, realia, models, dioramas and exhibits are } \\
\text { available to expedite the teaching-learning process. }\end{array}$ & 4.00 & Moderately well ready \\
$\begin{array}{l}\text { 5. There are aids such as rules and templates to save time } \\
\text { and improve students' quality of work. }\end{array}$ & 4.33 & Very well ready \\
$\begin{array}{l}\text { 6. Varied teaching techniques can be applied to selected } \\
\text { instructional materials }\end{array}$ & 4.67 & Very well ready \\
\hline
\end{tabular}

In terms of teachers' readiness to teach Purposive Communication in terms of instructional materials, 4 among the 6 statements ensued "very well ready" QI. Statements "Instructional materials are consistent with students' capabilities and learning styles." and "Varied teaching techniques can be applied to selected instructional materials." ensued the highest mean 4.67. "Instructional materials motivate and sustain the varied interests of the students." and "There are aids such as rules and 
templates to save time and improve students' quality of work." resulted to 4.33 mean. The 4 statements yielded "very well ready" QI. With a mean of 4.00, the statements "Instructional materials are based on teachers' suitability to attain the objectives of the lesson." and "Mock-ups, realia, models, dioramas and exhibits are available to expedite the teaching-learning process." resulted to "Moderately well ready" QI.

Brooke (2018) confirms the findings of the above result stating that with the use of effective instructional strategies and appropriate materials greatly reflects teacher effectiveness. There was also a provision and utilization of instructional materials on the paper of Bello (1999) which mentions that the use of these will promote students' intellectual ability and reflects teacher readiness to teach the subject. Likewise, the use of IMS proves to be effective in terms of sustaining and attracting students' attention and making them more interested on the topic irrespective of their gender (Thompson, 2001).

\section{Qualitative Phase}

The interview data is presented below following the themes decoded and generated in the interview transcript. The interview was designed to be flexible and responsive in relation to the questions asked to the participants, thus, participants' responses to the questions revealed their deep knowledge on the matter presented before them.

\section{Theme 1. Requalifying and Retooling the Teachers}

Pursuant to CMO No. 50 s. 2016, the Faculty Training for the New General Education Courses was conducted in different universities. Likewise, the training of GE Trainers and 2nd-Generation GE Faculty Training were conducted in 2016 and 2017 following the provisions of the CMO. In Isabela State University, faculty training was conducted in May 2018 where trained and CHED accredited trainers who are also faculty members of the university facilitated the lectures and workshops. Likewise, national trainings were conducted where faculty members of the university participated the said trainings. These trainings attended and participated by the faculty members made them ready to teach Purposive Communication. Confirmatory responses were:

The university sent our selected faculty members to attend trainings in preparation for the implementation of this new curriculum. Relatively, the university organized echo-training seminar-workshop for other concerned faculty members who will be handling Purposive Communication. The trainings made us feel prepared and ready for its implementation most especially the trainers gave us materials and presentations related to the subject. (R3)

However, even though trainings were conducted, the participants also feel there should be more trainings on Purposive Communication be conducted for them to cope with the demands of this new curriculum and new course. As the participants state:

I still get confused on the sequencing of subjects (topics) to be taught in PC, so trainings and workshops should still be conducted along this line. (R2)

More trainings for GEC teachers should be conducted. (R3)

These accounts that the faculty members handling Purposive Communication were retooled, trained and qualified to teach the course but needs more training to further enhance their skills and competencies in teaching Purposive Communication.

\section{Theme 2. Curriculum Reform and Realignment}

Before the implementation of the new GEC, the curriculum was totally revised pursuant to CHED Memorandum Order No. 20, series of 2013. Curriculum revision was accomplished by the faculty members, department heads and other university officials directly involved in this paradigm shift. Persons involved see to it that these new curriculum meets the needs of learners and is aligned to Philippines Qualification Framework, university's vision and mission and program's PSG. Responses of the participants confirm further that these has been done before the implementation of the new GEC and before they teach Purposive Communication.

We have several meetings regarding curriculum revision. Trainings and workshops on OBE and Curriculum revisions were conducted. Our VP ARA and DI required us to submit the revised AB English curriculum and the proposed syllabi for Purposive Communication. (R4) 
Curriculum revision was conducted I think 1 year or so before the implementation of the new GEC. As for Purposive Communication, I remember 2 or 3 workshops concerning the drafting and finalizing of its course content/syllabi, IMs and the like. (R2)

Each faculty member of every department was tasked to participate in the curriculum revision patterned in the implementation of the new GEC. (R8)

The statements above established the quality of the revised curriculum. Syllabi and other materials were prepared before its implementation. These papers were checked and edited by experts, thus undergone quality control.

\section{Theme 3. Teacher Preparation}

Since Purposive Communication is a new GE course, the need to prepare its syllabus, instructional materials, activities/worksheets, classroom, facilities and the like following its implementation's policies, standards and guidelines (PSG). Considering mostly the PSG of the academic programs in the university, school facilities and materials needed in Purposive Communication were readily prepared by the faculty and administrators involved. Statements of the participants confirm these preparations.

I made an IM for the subject. I created PPTs and other media for the subject. We also checked the Speech Laboratory, the equipment, classrooms, multimedia devices to be used in teaching this course. (R5)

I attended various seminar-workshops on Purposive Communication and read materials related to Purposive Communication. (R3)

We are encouraged at first then required to come-up with IMS as part of the preparation of its implementation. The course syllabi were also drafted, 1 syllabus per course, specifically designed for each and every course. (R7)

These confirmatory statements clearly state that syllabi, instructional materials, ICT equipment, Speech Laboratory and classrooms were prepared before class started.

\section{Theme 4. Effective Classroom Pedagogy}

The learners of Purposive Communication are the first graduates of the K-12 Basic Education Program. Likewise, these learners came from different schools and locations. Thus, the Purposive Communication classroom is a dynamic environment, bringing together students from different backgrounds with various abilities and personalities. Teachers' ability to use varied teaching methods and techniques should be considered to achieve effective teaching-learning process. Participants mentioned different strategies and techniques in teaching Purposive Communication. One participant enumerated strategies she used in teaching the course. The rest mentioned other pedagogies.

Since Purposive Communication is a course consists of varied subject matter, I am using varied teaching strategies and techniques to enhance student learning. I am using lecture, group report, individual presentation, simulation and gives them individual and group projects. (R1)

I make sure that students participate every meeting/discussion thru recitation and physical activities related to the subject matter. (R2)

Cooperative learning and incorporating technology in to my teaching is a great way to actively engage my students. Also, implementing an effective behavior management strategy and employing effective motivational techniques. (R3)

The participants' responses endorse further that since the Purposive Communication classroom consists of different persona and personalities making it difficult to address the individual needs of the learners. However, through effective use of different teaching strategies, techniques and methodologies ensure the effectivity of the teaching-learning process.

\section{Theme 5. Issues, Problems and Concerns}

Teachers' readiness to teach Purposive Communication has been proved through teacher training, quality curriculum, prepared materials and teaching strategies and methodologies. Though they mentioned they are very well ready to teach Purposive 
Communication, they still raised issues, problems and concerns in teaching the course. Participants mentioned of students' behavior, classroom facilities, number of students per class and subject matter.

The available media/ technology is not sufficient/ available for students' use. Students are also congested in the classroom. (R6)

I still get confused on the sequencing of subjects (topics) to be taught in PC. (R4)

Our first year students seem not interested with the topics most especially when the subject matter shifts from one topic to the other. The non-continuity of subject matter in PC is one of my problems in teaching the subject. (R8)

The issues, problems and concerns raised by the participants transpired during the recorded interview confirms that the university as well as the teachers handling the subject should engage themselves in the improvement of its course materials, classroom facilities and should procure additional ICT materials for students' use.

The quantitative part of the study clearly states that the teachers are ready to teach Purposive Communication where they mostly rated the statements in teaching competencies, teaching strategies, and instructional materials as "very well ready." specifically underscoring the result of each category, in terms of teaching competencies, 4 out of 6 statements reflected as "very well ready" and the other 2 as "moderately well ready" which imply that the teachers of Purposive Communication are really qualified and competent to teach the subject. These results were confirmed by the overall results of the qualitative part of the study. The participants mentioned that because of retooling, training, participating in curriculum revision and OBE training made them feel ready to teach Purposive Communication.

It is also evident that the respondents are "very well prepared" in terms of teaching strategies as revealed by the results of the study. These corroborates with the statements of the participants in the recorded interview that they are using varied teaching strategies, methodologies and techniques for the students to fully understand the subject matter. The effectivity and continuous flow of the teaching and learning process in the classroom is highly dependent on teachers' way of imparting knowledge to the learners. This implies further that since varied learners' personality and capacity to understand lessons are present in the Purposive Communication classroom, the use of varied teaching strategies and methodologies enhances and heightens the probability that students will easily grasp the idea the teacher wanted to convey to them. Teachers' adeptness in using the strategies concludes that they really are prepared to face the challenges of this new course.

Instructional Materials, one of the salient areas in this curriculum reform, was also analyzed in this study. The data revealed that there were available materials to be used in teaching Purposive Communication. The respondents rated "very well prepared" in almost all of its statements. It is also apparent that during the recorded interview, the participants confirmed that there are books, PowerPoint presentations and lecture notes available. The course-specific syllabus was also finalized. Authors of one book used are faculty members of the university as stressed by the participants. This suggests that before the implementation of the curriculum reform the faculty members involved already prepared the materials needed in teaching Purposive Communication.

Problems, issues and concerns were also marked on the responses of the participants of the study. They revealed that though they are "very well ready" because of various retooling program and there were a number of available resources, still there is a need to attend and participate in trainings and workshops related to the teaching of Purposive Communication. Because of the issue on the non-continuity of subject matter, as highlighted by one of the participants, the course contents should be revised and polished based on the needs of the learners. Couse-specific syllabi should also be revised based on the PSG of the program. School facilities and number of students in each class were also mentioned where it shows that in terms of readiness to teach, they are "very well ready" but there are also areas that somewhat show the lack the readiness to start the new course. Therefore, the need to procure ICT materials to facilitate effective learning should be one of the priorities of the management.

\section{Conclusion}

The implementation of this curriculum reform poses several issues regarding the readiness of stakeholders in all its aspects. The results of this study aimed at confirming the readiness of the most important people involved in the implementation of 
this paradigm shift- the teachers. Their readiness to teach Purposive Communication plays a great role in the effectiveness of its implementation.

Quantitative and qualitative results confirmed the readiness of teachers in teaching Purposive Communication. Though the course requires higher order thinking skills as reflected in its course description, teachers are very well prepared to accept the challenge of this new course. Issues, problems and concerns were also mentioned but this does not imply that the teachers are not ready to address these, results then confirm that in most of its areas, the teachers are very well ready to handle the subject.

On the contrary, the study only focuses on three aspects of the course, research on usefulness of the prepared instructional materials, worksheets and the like may be conducted to track the effectivity of its usage. Class observation may also be used as a tool to triangulate and cross confirm the results of this study. Furthermore, since the issue on facilities was raised, it is necessary therefore to delve into the preparedness of the university in terms of school facilities and ICT equipment which are needed in teaching Purposive Communication. It is also recommended that preparedness of teachers in teaching the new general education curriculum under the new normal teaching-learning process should also be monitored.

\section{References}

[1] Acosta, A. (2017). Teachers' perceptions on senior high school readiness of higher education institutions in the Philippines. Universal Journal of Educational Research 4(10).

[2] Ahmadi (2015). Issues and prospects of effective implementation of new secondary school curriculum in Nigeria. Journal of Education and Practice, 6(34).

[3] Allinder, R. M. (1995). An examination of the relationship between teacher efficacy and curriculum-based measurement and student achievement. Remedial and Special Education, 16(4).

[4] Anderson, R., Greene, M., \& Loewen, P. (1988). Relationships among teachers' and students' thinking skills, sense of efficacy, and student achievement. Alberta Journal of Educational Research, 34(2).

[5] Babalola, J. (2004). Management of primary and secondary education in Nigeria. NAEP Publication, Ibadan.

[6] Chikumbi, N. \& Makamure, T. (2005) Training teachers for quality education in Europe. European Journal of Teacher Education, 25(1).

[7] CMO No. 20, s. of 2013. General Education Curriculum: Holistic Understandings, Intellectual and Civic Competencies.

[8] Cochran-Smith, M., \& Zeichner, K. (2005). Studying teacher education: The report of the AERA panel on research and teacher education. Mahwah, NJ: Lawrence Erlbaum.

[9] Creswell, J. (1999). Mixed method research: Introduction and application. In T. Cijek (Ed.), Handbook of educational policy (pp. 455472). San Deigo, CA: Academic PressCreswell, J. (2002). Educational research: Planning, conducting, and evaluating quantitative and qualitative approaches to research. Upper Saddle River, NJ: Merrill/Pearson Education.

[10] Creswell, J. W. (2003). Research design: Quantitative, qualitative, and mixed methods approaches (2nd ed.). Thousand Oaks, CA: Sage.

[11] Darling-Hammond, L. (2009). Educational opportunity and alternative certification: New evidence and new questions, Policy Brief No. 1. Stanford, CA: Stanford Center for Opportunity Policy in Education.

[12] Darling-Hammond, L. \& J. Baratz-Snowden. (2005). A good teacher in every classroom: Preparing the highly qualified teachers our children deserve. San Francisco, CA: John Wiley \& Sons.

[13] Dyer, J. E., \& Osbome, E. W. (1995). Effects of teaching approach on achievement of agricultural educatoin students with varying learning styles. Proceedings of the 22nd Annual National Agricultural Education Research Meeting, 22.

[14] Gutmann, M. L., \& Hanson, W. E. (2003). Advanced mixed methods research designs. In A. Tashakkori \& C. Teddlie (Eds.), Handbook of mixed methods in social and behavioral research. Thousand Oaks, CA: Sage.

[15] Hamachek, D. E. (1969). Characteristics of good teachers and implications for teacher education. Phi Delta Kappan, 50.

[16] Hargreaves, A., \& Fullan, M. (2012). Professional capital: Transforming teaching in every school. Routledge.

[17] Harris, D. \& Sass, T. (2011). Teacher training, teacher quality and student achievement. Journal of Public Economics, 95(7).

[18] Howe, N., \& Strauss, W. (2000). Millennials rising: The next great generation. New York: Vintage Books.

[19] Hwande E. \& John M. (2017). The readiness of primary schools to implement the new curriculum in Zimbabwe at ECD (a) level: A case study of bandura urban primary schools. European Journal of Education Studies, 3(7).

[20] Jesse R. (2010). Teacher quality in educational production: Tracking, decay, and student achievement. The Quarterly Journal of Economics, 125(1).

[21] Kazmer, Michelle M. \& Xie, B. (2008). Qualitative interviewing in internet studies: Playing with the media, playing with the method. Information, Communication, and Society, 11(2).

[22] Kimosop (2015). Teacher preparedness for effective classroom instruction of the secondary school Christian religious education curriculum in Kenya. International Journal of Scientific Research and Innovative Technology, 2(12).

[23] Kvale, S. (1996). Interviews: An introduction to qualitative research interviewing. Thousand Oaks, CA: Sage.

[24] Lachat, M. A., \& Smith, S. (2005). Practices that support data use in urban high schools. Journal of Education for Students Placed at Risk, 10.

[25] Leithwood, K., Mascall, B., Strauss, T., Sacks, R., Memon, N., \& Yashkina, A. (2007). Distributing leadership to make schools smarter: Taking the ego out of the system. Leadership and Policy in Schools, 6(1). 
[26] Lynch, D. \& Smith, R., (2016). Readiness for school reform. International Journal of Innovation, Creativity and Change, 2(3).

[27] Lynch, D., Smith, R., Provost, S., Yeigh, T. \& Turner, D. (2017). The correlation between 'Teacher Readiness' and student learning improvement. International Journal of Innovation, Creativity and Change, 3(1).

[28] Makunja, G. (2016). Challenges facing teachers in implementing competence-based curriculum in Tanzania: The case of community secondary school in Morogoro Municipality. International Journal and Social Science, 3(5).

[29] Mkpa, M. (2005). Challenges of implementing the school curriculum in Nigeria. Journal of Curriculum Organization of Nigeria 12(1).

[30] Okello, V. \& Kagoire, M. (1996). An evaluation of the English language curriculum of the Nigeria certificate in education: A case study of a College of Education, Makero University Curriculum Studies Module. Bezatel Design Studies, 9.

[31] Rossman, G. B., \& Wilson, B. L. (1985). Numbers and words: Combing quantitative and qualitative methods in a single large-scale evaluation study. Evaluation Review, 9.

[32] Sanders, W. L., \& Horn, S. P. (1998). Research findings from the Tennessee Value-Added Assessment System (TVAAS) database: Implications for educational evaluation and research. Journal of Personnel Evaluation in Education, 12(3).

[33] Shinn, Y. (1997). Teaching strategies, their use and effectiveness as perceived by teachers of agriculture: A national study. Retrospective Theses and Dissertations.

[34] Tashakkori, A., \& Teddlie, C. (1998). Mixed methodology: Combining qualitative and quantitative approaches. Thousand Oaks, CA: Sage Publications.

[35] Wagner, T. (2008). The global achievement gap: Why even our best schools don't teach the new survival skills and what we can do about it. New York, NY: Basic Books. 